を生ずるに至る。们て最初心酸店老 $2 N$ とすれば約 2 䢙間は保存出来る。

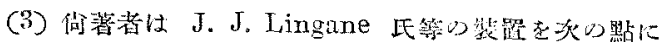
就て改良を試灭良結果起得た。

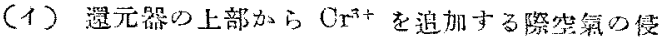

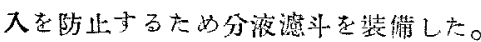

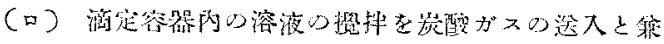

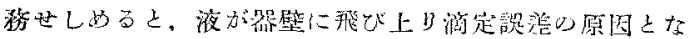

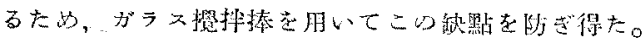

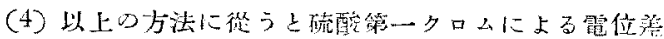

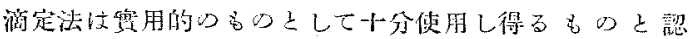

to

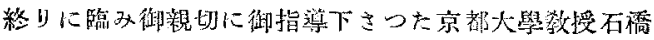

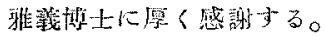

一文献 -

1) Buchrer \& Schupp, Ind. Eng. Chem, 18, 121 (1926).

2) Zintl \& Rienäcker, Z. anorg. Chem, 161, 374 (1927).

3) J. J. Lingane \& R. L. Pecsok, J. Anat. Chem., 20, $425(1948)$.

\title{
アルキノールの曂位反應に就て（第、報） イップロピルエテニルカービノールに對する硫酸の作用
}

\author{
市來㟨馓・金田一正弘
}

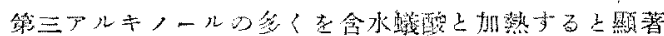

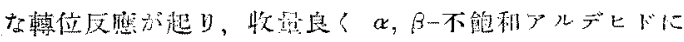

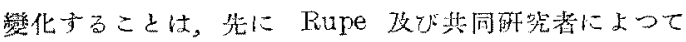

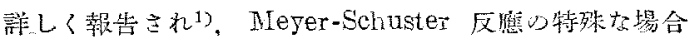
として說明された。

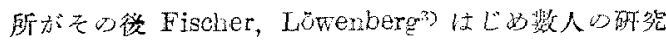

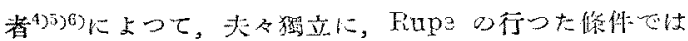

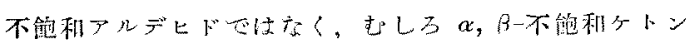
が得られるとの反證方行わ机、精巧小分析法によつて子

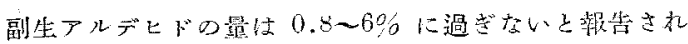
るК至つだ。

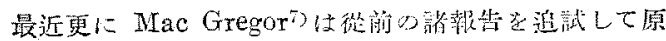

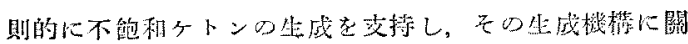
しては，先ず㧤ヒドロキシルに上るカルボニるムイオン の生成が第一階程に起り，沃に绦接の炭素からプロトン

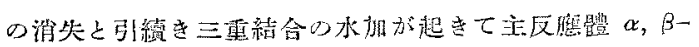

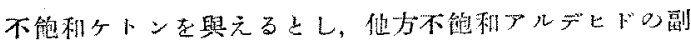

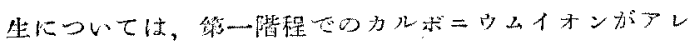

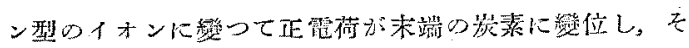
の部分にヒドロキシル化が起るために，副生不館和アル デヒドと平衡在保つエノル型アルデヒドを生じるるのる した。Mac Gregor 自身の筫醶匹゙，初生のカルボニウム イオンからプロトンの消失が起らないフェニルェチ=ル

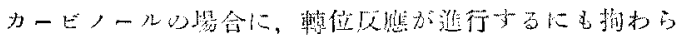

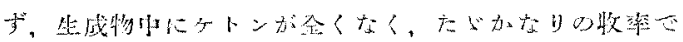

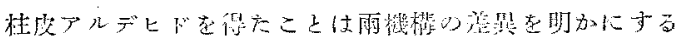
默て與味るるるのでるる。

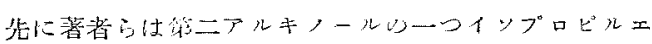

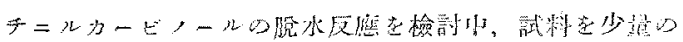

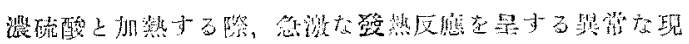

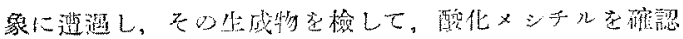

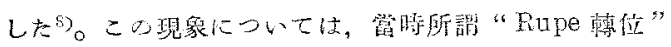

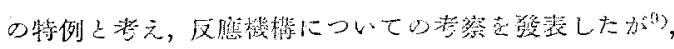

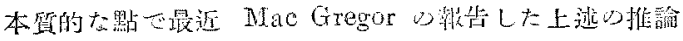

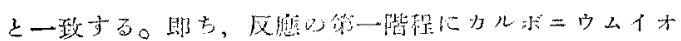

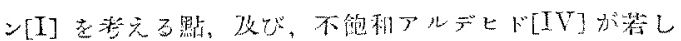

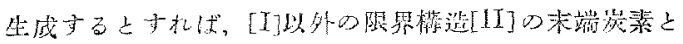

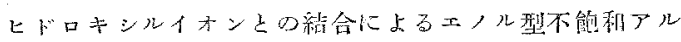
デヒドを經て尘お゙ぶき點ですが，

$$
\begin{aligned}
& \mathrm{Me}_{2} \mathrm{OH} \cdot \mathrm{CH}(\mathrm{OH}) \cdot \mathrm{C} \equiv \mathrm{CH} \\
& \text { インプロビルェチ=n } \\
& \text { »ービノール } \\
& \longrightarrow\left[\mathrm{Me}_{2} \mathrm{OH} \cdot \stackrel{\mathrm{C} \cdot \mathrm{C} H}{\mathrm{C}} \cdot \mathrm{O} \equiv \mathrm{CH}\right]
\end{aligned}
$$

[1]

$\longrightarrow\left[\mathrm{Me}_{2} \mathrm{CH} \cdot \mathrm{CH}=\mathrm{O}=\stackrel{(+)}{\mathrm{C}} \mathrm{H}\right]$

[II] 
$\longrightarrow \mathrm{Me}_{2} \mathrm{CH} \cdot \mathrm{CH}=\mathrm{C}=\mathrm{CH} \cdot \mathrm{OH}$

[III]

$\rightleftarrows \mathrm{Me}_{2} \mathrm{CH} \cdot \mathrm{CH}=\mathrm{CH} \cdot \mathrm{CHO}$

[IV]

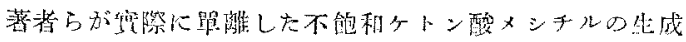

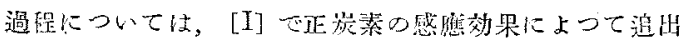

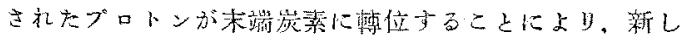

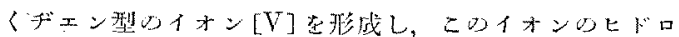

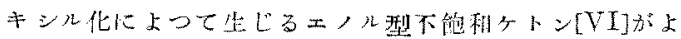

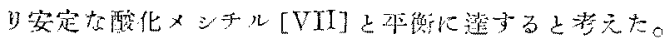

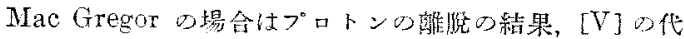

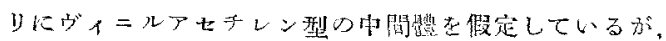

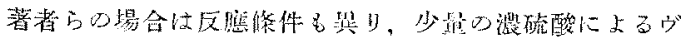

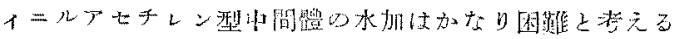

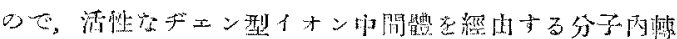
位己して訟昒している。

[I] $\longrightarrow\left[\mathrm{Me} \cdot \mathrm{C}=\mathrm{CH} \cdot\left(+\mathrm{O}=\mathrm{CH}_{2}\right]\right.$

[V]

$\longrightarrow \mathrm{He}_{2} \mathrm{C}=\mathrm{CH} \cdot \mathrm{C}(\mathrm{OH})=\mathrm{CH}_{2}$ [VI]

$\rightleftarrows \mathrm{HLe} \mathrm{O}=\mathrm{OH} \cdot \mathrm{OO} \cdot \mathrm{CH}_{3}$

[VII]

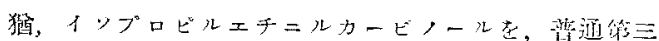

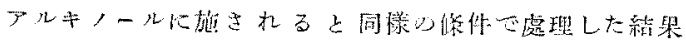

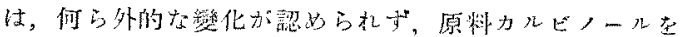

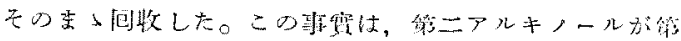

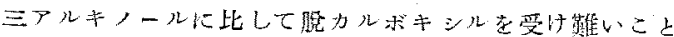

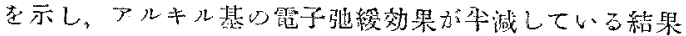
と教えら机，又著者方先にイソプロビルヴィニルカービ

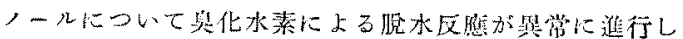

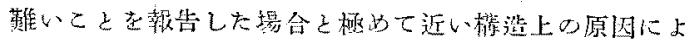
るものた娄 5 。

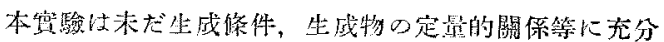

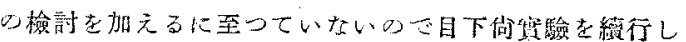
ている。

\section{實 驗 の 部}

\section{I. イソプロビルエチニルカービノール $1 l$ の辰型} シロフラスコに嚓つた $300 \mathrm{cc}$ の乾燥液體アンモニアに

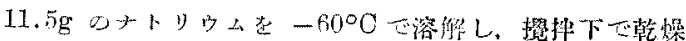
アセチレン吸收させて溶液の清色が全く消笑したなら ばアセチレンの淔入を止め，36gのイッブチラルデヒド

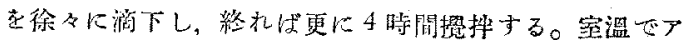

ンモニアを追出した白色残留物に氷水を加えて溶解さ

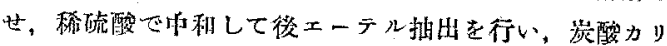

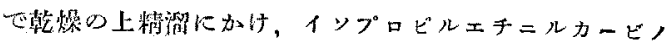

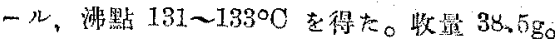

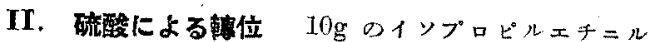

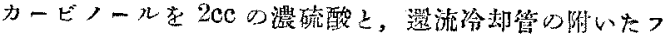

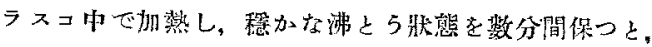

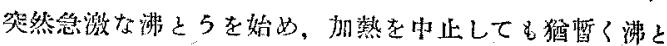

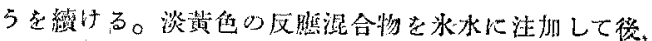
荻酸ソーダで中和の上エー リで槹嬠して分溜す好ば，主溜分として $120 \sim 140^{\circ} \mathrm{C}$ の 特琴臭るる淡黄色口液盟を得，酸化メシチルの存在を思

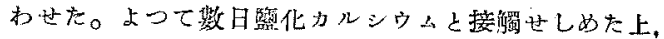

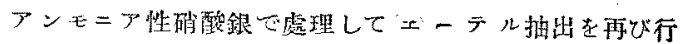

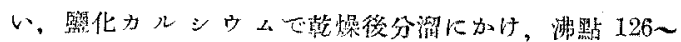

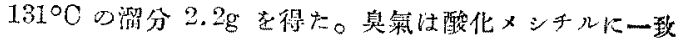

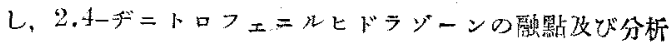
值上り酸化メシチルを硪証した。

$$
\begin{aligned}
& \text { 2.4-デニトロフェニルヒドラジーン(アルコールより) } \\
& \text { 剭點 } 201 \sim 2 \circ \mathrm{C} \\
& \text { 分析：N } 19.80 \% ， 19.78 \% \\
& \mathrm{C}_{22} \mathrm{H}_{14} \mathrm{O}_{4} \mathrm{~N}_{4} \text { としての計算做 } 20.03 \%
\end{aligned}
$$

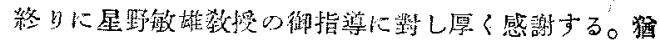

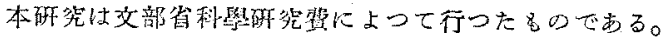

\section{一交献 -}

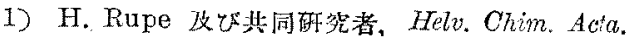
$9,672(1926) ; 11,449,656,965(1928) ;$ 14, 687, 701, 708 (1981).

2) K. H. Meyer, K. Schuster, Ber., 55, 819 , (1922).

3) F. G. Fischer, K. Löwenberg, Ann., 475, 183 (1929).

4) C. D. Hurd, R. E. Christ, I. Am. Chem. Soc, 59,118 (1937).

5) C. C. Price, S. Meisel, ibid., 69, 1497(1947).

6) J. D. Chanley, ibid, 70, 224 (1948).

7) W. Mac Gregor, ibid., 70, 3953 (1948).

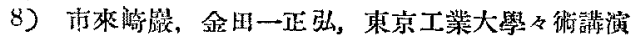
(July 3. 1948).

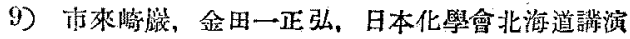
(July 30. 1949).

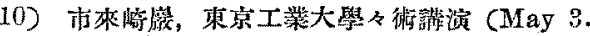
1947). 